\title{
Influence of increased doses of detoxified castor bean meal on chemical composition and characteristics of sugarcane silage
}

\author{
Aryane da S. Paulino¹, Vitor V.S. de Almeida ${ }^{1}$, Aline C. Oliveira ${ }^{1}$, Hellenn C. Oliveira², Rasmo Garcia², \\ Robério R. Silva ${ }^{3}$, Patrícia dos Santos ${ }^{1}$, Yara A. da Silva ${ }^{1}$, Shayane B. Bispo ${ }^{1}$, \\ and Dorgival M. de Lima-Júnior ${ }^{1^{*}}$
}

${ }^{1}$ Universidade Federal de Alagoas, Campus Arapiraca, 57309-005, Alagoas, Brasil. .Corresponding author (juniorzootec@yahoo.com.br). ${ }^{2}$ Universidade Federal de Viçosa, Viçosa, 36570-900, 45700-000, Minas Gerais, Brasil.

${ }^{3}$ Universidade Estadual do Sudoeste da Bahia, Itapetinga, 45700-000, Bahia, Brasil.

Received: 12 June 2018; Accepted: 24 September 2018; doi:10.4067/S0718-58392018000400503

\begin{abstract}
Sugarcane (Saccharum officinarum L.) ensilage presents serious limitations due to the conversion of soluble carbohydrates into ethanol, thus, it is necessary to use additives that reduce losses of DM during the ensilage process. The aim of this study was to evaluate the effect of increasing levels of detoxified castor-bean (Ricinus communis L.) meal (DCBM) on the nutritive value, fermentation pattern, stability and losses of sugarcane silages. Twenty mini-silos with sugarcane and five different concentrations of DCBM $\left(0,50,100,150\right.$ and $200 \mathrm{~g} \mathrm{~kg}^{-1}$ fresh matter) were prepared in a completely randomized design with five replicates per treatment. After $60 \mathrm{~d}$, silage was sampled to determine chemical-bromatological composition, fractionation of carbohydrates and protein content, ammoniacal $\mathrm{N}\left(\mathrm{N}-\mathrm{NH}_{3}\right)$ and losses through gases and effluents. The addition of DCBM increased $(\mathrm{P}<0.05) \mathrm{DM}$ content, crude protein, fraction $\mathrm{A}+\mathrm{B} 1$ of the total carbohydrates. However, it reduced $(\mathrm{P}<0.05)$ the levels of neutral and acid detergent insoluble fiber, fraction $\mathrm{B} 1+\mathrm{B} 2$ of total $\mathrm{N}$ and $\mathrm{N}-\mathrm{NH}_{3}$. The addition of DCBM reduced the losses of total DM but decreased silages aerobic stability. The addition of $150 \mathrm{~g} \mathrm{~kg}^{-1}$ DBCM improved the nutritional value, fermentation pattern and reduced losses of sugarcane silages.
\end{abstract}

Key words: Biodiesel residue, fractionation of carbohydrates, Ricinus communis, Saccharum officinarum, silage effluent.

\section{INTRODUCTION}

Sugarcane (Saccharum officinarum L.) is cultivated throughout the global tropical zone mainly for the production of sugar and ethanol. Due to the high yield of fresh mass $\left(80 \mathrm{tha}^{-1}\right)$ and high soluble carbohydrate content $\left(396 \pm 109 \mathrm{~g} \mathrm{~kg}^{-1}\right)$ (Daniel et al., 2013a), sugarcane is potentially used for animal feeding. The main obstacle to use sugarcane as exclusive roughage is the reduced crude protein levels $\left(55.5 \pm 46.8 \mathrm{~g} \mathrm{~kg}^{-1}\right)$ (Daniel et al., 2013b) and the high labor cost in logistic operations (Siqueira et al., 2012).

Sugarcane ensilage is an operational solution that reduces the daily need for labor. However, the conservation of sugarcane by acidification presents serious limitations due to the losses through effluents (Cavali et al., 2010). In addition, there are inconsistent results of the use of microbial additives in reducing losses and improving nutritive value of sugarcane silage (Novinski et al., 2012; Santos et al., 2015). Thus, it is necessary to use additives that are capable of improving the fermentation pattern of sugarcane silages and reduce losses of DM during the ensilage process (Andrade et al., 2016).

Castor-bean (Ricinus communis L.) is a widespread castor oil in the global tropics, which presents many applications such as paints, varnishes and biodiesel production. In this context, after oil extraction via solvent, remains a toxic residue, 
named castor-bean meal, which could be used in animal feeding after being detoxified. After detoxification, alkalinization promoted by calcium hydroxide causes ricin denaturation (Oliveira et al., 2010), castor-bean meal presents $900 \pm 26 \mathrm{~g} \mathrm{~kg}^{-1}$ $\mathrm{DM} ; 340 \pm 83 \mathrm{~g} \mathrm{~kg}^{-1}$ crude protein; $30 \pm 1.9 \mathrm{~g} \mathrm{~kg}^{-1}$ ether extract; $460 \pm 72 \mathrm{~g} \mathrm{~kg}^{-1}$ neutral detergent fiber; $60 \pm 4.9 \mathrm{~g} \mathrm{~kg}^{-1}$ non-fibrous carbohydrates, and $180 \pm 64 \mathrm{~g} \mathrm{~kg}^{-1}$ lignin (Gionbelli et al., 2014; Menezes et al., 2015; Freire et al., 2017). Therefore, detoxified castor-bean meal is an absorbent and protein additive capable of improving the fermentation process in sugarcane silage, reducing gas and effluent losses and raising protein content of silage (Moreira et al., 2014; 2016).

The aim of this work was to evaluate the nutritional value, fermentation profile and losses in sugarcane silages supplemented with increasing levels of detoxified castor-bean meal.

\section{MATERIALS AND METHODS}

The experiment was conducted in the municipality of Arapiraca ( $\left.09^{\circ} 45^{\prime} 09^{\prime \prime} \mathrm{S}, 36^{\circ} 39^{\prime} 40^{\prime \prime} \mathrm{W}\right)$, Alagoas, Brazil. The whole plant sugarcane (Saccharum officinarum L.) var. RB07312 was used, and it was harvested at 18-mo without burning. The forage processing for ensilage was in a stationary chopper to obtain particles with an average size of $2 \mathrm{~cm}$. After processing, sugarcane was homogenized and mixed with detoxified castor-bean meal. The castor-bean meal was previously detoxified through the use of calcium hydroxide solution $\left(\mathrm{Ca}(\mathrm{OH})_{2}\right)$ as recommended by Oliveira et al. (2010). After mixing castor-bean meal with the $\left(\mathrm{Ca}(\mathrm{OH})_{2}\right)$ solution, the material remained still for $12 \mathrm{~h}$ at $25^{\circ} \mathrm{C}$. Then it was dried through sun exposure.

Detoxified castor-bean meal (DCBM) was added at 0,50,100,150, $200 \mathrm{~g} \mathrm{~kg}^{-1}$ fresh matter (w/w) to sugarcane forage and immediately ensiled in 25 plastic buckets (five per treatment), with $32 \mathrm{~cm}$ of height and $88 \mathrm{~cm}$ of diameter provided with Bunsen valves for the elimination of fermentation gases. Three kilograms of fine sand was added to the bottom of each bucket to drain effluents, and a screen was used to separate the sand from the silage. Compaction was performed to obtain a density of $600 \mathrm{~kg} \mathrm{~m}^{-3}$. Silos were sealed, weighed and stored in shade for $60 \mathrm{~d}$. Fresh samples of sugarcane and DCBM were collected for analysis of chemical composition (Table 1).

After $60 \mathrm{~d}$, silos were weighed again to estimate total losses of DM $\left(\mathrm{g} \mathrm{kg}^{-1} \mathrm{DM}\right)$, losses through gases (LG), losses through effluent (LE) and DM recovery index (DMRI) according to equations proposed by Jobim et al. (2007). The silages of each bucket were also sampled. The collected samples were properly identified, conditioned and stored in a freezer at $-10{ }^{\circ} \mathrm{C}$. Subsequently, part of the samples were thawed at room temperature for pre-drying in a forcedventilation oven at controlled temperature $\left(55^{\circ} \mathrm{C}\right.$ for $\left.72 \mathrm{~h}\right)$. Then they were ground in a Willey-type mill, sieved with $1 \mathrm{~mm}$ mesh and subjected to analysis of DM (ID 930.15), ashes (942.05), crude protein (CP) (ID 954.01), and ether

Table 1. Chemical composition of detoxified castor-bean meal (DCBM) and sugarcane forage supplemented or not with DCBM before ensiling.

\begin{tabular}{|c|c|c|c|c|c|c|}
\hline \multirow[b]{2}{*}{ Variable } & \multirow[b]{2}{*}{ DCBM } & \multicolumn{5}{|c|}{ Levels of DCBM $\left(\mathrm{g} \mathrm{kg}^{-1} \mathrm{FM}\right)$} \\
\hline & & 0 & 50 & 100 & 150 & 200 \\
\hline Dry matter, $\mathrm{g} \mathrm{kg}^{-1} \mathrm{FM}$ & 925.2 & 275.9 & 279.6 & 308.1 & 324.9 & 347.5 \\
\hline Mineral matter, $\mathrm{g} \mathrm{kg}^{-1} \mathrm{DM}$ & 124.2 & 17.0 & 37.7 & 52.2 & 61.5 & 78.9 \\
\hline Crude protein, $\mathrm{g} \mathrm{kg}^{-1} \mathrm{DM}$ & 448.4 & 26.6 & 85.1 & 123.7 & 147.0 & 216.6 \\
\hline Neutral detergent fiber corrected for ashes and protein, $\mathrm{g} \mathrm{kg}^{-1} \mathrm{DM}$ & 375.2 & 455.7 & 488.9 & 468.5 & 473.8 & 480.6 \\
\hline Hemicellulose, $\mathrm{g} \mathrm{kg}^{-1} \mathrm{DM}$ & 46.2 & 71.9 & 97.8 & 87.4 & 88.3 & 90.1 \\
\hline Cellulose, $\mathrm{g} \mathrm{kg}^{-1} \mathrm{DM}$ & 121.8 & 363.1 & 380.3 & 352.6 & 348.8 & 306.0 \\
\hline Ether extract, $\mathrm{g} \mathrm{kg}^{-1} \mathrm{DM}$ & 27.0 & 14.9 & 14.0 & 15.9 & 22.2 & 23.9 \\
\hline Acid detergent fiber, $\mathrm{g} \mathrm{kg}^{-1} \mathrm{DM}$ & 359.0 & 413.1 & 435.7 & 395.2 & 424.0 & 401.4 \\
\hline Lignin, $\mathrm{g} \mathrm{kg}^{-1} \mathrm{DM}$ & 300.9 & 78.4 & 108.5 & 125.4 & 159.8 & 183.3 \\
\hline Neutral detergent insoluble $\mathrm{N}, \mathrm{g} \mathrm{kg}^{-1} \mathrm{DM}$ & 29.7 & 6.2 & 7.9 & 11.1 & 13.7 & 17.5 \\
\hline Acid detergent insoluble $\mathrm{N}, \mathrm{g} \mathrm{kg}^{-1} \mathrm{DM}$ & 20.0 & 1.8 & 5.7 & 8.2 & 10.8 & 14.3 \\
\hline Neutral detergent insoluble $\mathrm{N}, \mathrm{g} \mathrm{kg}^{-1} \mathrm{CP}$ & 354.8 & 451.5 & 577.0 & 560.3 & 583.4 & 504.3 \\
\hline Acid detergent insoluble $\mathrm{N}, \mathrm{g} \mathrm{kg}^{-1} \mathrm{CP}$ & 238.6 & 424.6 & 419.0 & 412.0 & 457.4 & 412.9 \\
\hline Total digestible nutrients, $\mathrm{g} \mathrm{kg}^{-1} \mathrm{DM}$ & 671.5 & 600.8 & 546.7 & 553.6 & 431.3 & 532.2 \\
\hline Total carbohydrates, $\mathrm{g} \mathrm{kg}^{-1} \mathrm{DM}$ & 418.0 & 950.2 & 863.3 & 808.2 & 843.0 & 680.6 \\
\hline Non-fibrous carbohydrates, $\mathrm{g} \mathrm{kg}^{-1} \mathrm{DM}$ & 73.0 & 466.9 & 288.6 & 271.1 & 322.5 & 189.5 \\
\hline Indigestible neutral detergent fiber, $\mathrm{g} \mathrm{kg}^{-1} \mathrm{DM}$ & 292.4 & 173.8 & 235.2 & 236.2 & 223.5 & 259.5 \\
\hline In vitro DM digestibility, $\mathrm{g} \mathrm{kg}^{-1}$ & 645.1 & 712.6 & 630.8 & 626.0 & 632.2 & 661.2 \\
\hline
\end{tabular}

FM: Fresh matter; CP: crude protein. 
extract (EE) (ID 920.39) according to the procedures of AOAC (2005). Neutral detergent fiber (NDFap), acid detergent fiber (ADF) and lignin were determined according to methodology proposed by Van Soest et al. (1991). Cellulose and hemicellulose fractions were estimated by the following equations: Hemicellulose $=$ NDF - ADF; Cellulose $=$ ADF - acid detergent lignin (ADL). The percentage of total carbohydrates (TC) was obtained by the equation proposed by Sniffen et al. (1992): TC $=100-(\% \mathrm{CP}+\% \mathrm{EE}+$ ash). Fibrous carbohydrates were obtained from the NDF corrected for ashes and protein (NDFap); non-fibrous carbohydrate (NFC), i.e., the rapid degradation rate fractions (A + B1) were calculated by the difference between total carbohydrates and NDFap (Hall, 2003) and undegradable rate fraction (C), by indigestible NDF after $244 \mathrm{~h}$ of in situ incubation as described by Casali et al. (2008). The low degradation rate fraction (B2) was obtained by the difference between NDFap and fraction $\mathrm{C}$. The percentage of total $\mathrm{N}(\mathrm{TN})$ was obtained according to AOAC $(2005 ; 954.01)$. Fractions A (rapid degradation rate), B1 + B2 (rapid degradation rate), B3 (low degradation rate), and C (undegradable rate) of TN were obtained according to Sniffen et al. (1992). Neutral detergent insoluble N (NDIN) and acid detergent insoluble N (ADIN) were obtained according to Sniffen et al. (1992). For the determination of in vitro DM digestibility of the diets, the technique described by Tilley and Terry (1963) adapted to the artificial rumen, developed by ANKOM Technology (Macedon, New York, USA), as described by Holden (1999) was adopted.

Fresh silage ( $50 \mathrm{~g}$ ) was triturated with $200 \mathrm{~mL}$ water in an industrial blender and gauze filtered to extract the aqueous medium and immediately used for $\mathrm{pH}$ measurement (Silva and Queiroz, 2002) and ammonia $\mathrm{N}\left(\mathrm{N}-\mathrm{NH}_{3}\right)$ analysis (AOAC, 2005).

To evaluate the aerobic stability, the contents of each silo were homogenized and $4 \mathrm{~kg}$ silage were placed in buckets without compaction and exposed in a closed environment - room of $96 \mathrm{~m}^{2}$, clay tiled roof $-27.61 \pm 1.02{ }^{\circ} \mathrm{C}$ and $706.8 \pm$ $42.9 \%$ air RH. The silages temperatures were verified twice a day during $10 \mathrm{~d}$, using a thermometer inserted in the center of the forage mass, according to Bernardes et al. (2007). The accumulated temperature was calculated by summing the positive differences between the silage and room temperatures. The aerobic stability evaluation was calculated using the parameters proposed by O'Kiely et al. (1999).

Treatments were distributed in a completely randomized design, using the model: Yijk $=\mu+T i+e i j k$. In which Yijk is the observed value; $\mu$ is general constant; $T i$ is treatment effect $\mathrm{i}$; eijk is error associated with each observation. Data were evaluated through ANOVA and regression using the statistical software SAEG version 9.1 (Fundação Arthur Bernardes, Universidade Federal de Viçosa [UFV], Viçosa, Minas Gerais, Brazil). Coefficient of determination $\left(\mathrm{r}^{2}\right)$ was the criteria used to choose the model and was calculated as the ratio between the regression sum of squares and the sum of squares of treatments and the observed significance of the regression coefficients.

\section{RESULTS}

\section{Chemical-bromatological composition}

The addition of increasing doses of DCBM to sugarcane at the ensilage process increased linearly $(\mathrm{P}<0.001) \mathrm{DM}$ and $\mathrm{CP}$ contents of the silages (Table 2). Through the equation, it was estimated that for each $1 \mathrm{~g} \mathrm{~kg}^{-1}$ of DCBM added, there was an increase of $6.7 \mathrm{~g} \mathrm{~kg}^{-1} \mathrm{DM}$ and $7.1 \mathrm{~g} \mathrm{~kg}^{-1} \mathrm{CP}$ in the silage. The fibrous fractions (NDFap, ADF, cellulose and hemicellulose) of the silage were influenced by DCBM levels. For each unit of additive, there was a reduction of $118 \mathrm{~g} \mathrm{~kg}^{-1} \mathrm{NDFap}$ and $51 \mathrm{~g} \mathrm{~kg}^{-1} \mathrm{ADF}$ in DM of the silage. Nevertheless, in spite of the negative linear response of ADF, lignin content presented augmented linearly $(\mathrm{P}<0.001)$ with increasing amounts of DCBM. In vitro DM digestibility (IVDMD) was quadratically affected with a maximum point of $661.5 \mathrm{~g} \mathrm{~kg}^{-1}$ IVDMD at the level of $151.4 \mathrm{~g} \mathrm{~kg}^{-1}$ inclusion of DCBM.

Total carbohydrates (TC) and potentially digestible fibrous carbohydrates (B2) as a percentage of TC decreased linearly with increased amounts of DCBM (Table 3). Quadratic behavior was observed for carbohydrate fractions with high ruminal degradation rate $(\mathrm{A}+\mathrm{B} 1)$. The indigestible fraction $(\mathrm{C})$ also adjusted to the quadratic model $(\mathrm{P}<0.001)$ presenting a minimum point of $36.72 \mathrm{~g} \mathrm{~kg}^{-1}$ for the level $86.3 \mathrm{~g} \mathrm{~kg}^{-1}$ DCBM. Regarding $\mathrm{N}$ fractionation, total $\mathrm{N}$ content augmented linearly with increased amounts of DCBM. However, protein fractions of fast and intermediate degradation (B1 + B2) of TN presented a linear response dropping from 6.3 to $10 \mathrm{~g} \mathrm{~kg}^{-1}$ DCBM (Table 3). Increases of 0.21 and 0.38 $\mathrm{g} \mathrm{kg}^{-1}$ of the fractions $\mathrm{B} 3$ and $\mathrm{C}$ (slow degradation protein and non-degradable fraction, respectively) for each $10 \mathrm{~g} \mathrm{~kg}^{-1}$ DCBM added to the silages were also observed. 
Table 2. Chemical composition of sugarcane silages supplemented with different levels of detoxified castor-bean meal (DCBM) before ensiling.

\begin{tabular}{|c|c|c|c|c|c|c|c|c|c|c|}
\hline \multirow[b]{2}{*}{ Item } & \multicolumn{5}{|c|}{ Levels of DCBM $\left(\mathrm{g} \mathrm{kg}^{-1} \mathrm{FM}\right)$} & \multirow[b]{2}{*}{ Equation } & \multirow[b]{2}{*}{$\mathrm{r}^{2}$} & \multirow[b]{2}{*}{$\mathrm{CV}(\%)$} & \multicolumn{2}{|c|}{$P$ value } \\
\hline & 0 & 50 & 100 & 150 & 200 & & & & $\mathrm{~L}$ & Q \\
\hline Dry matter, $\mathrm{g} \mathrm{kg}^{-1} \mathrm{FM}$ & 193.4 & 228.7 & 271.6 & 301.3 & 324.5 & $\hat{\mathrm{Y}}_{1}$ & 0.99 & $2.93<$ & $<0.001$ & 0.009 \\
\hline Mineral matter, $\mathrm{g} \mathrm{kg}^{-1} \mathrm{DM}$ & 26.0 & 47.8 & 59.1 & 70.5 & 80.8 & $\hat{\mathrm{Y}}_{2}$ & 0.97 & $5.93<$ & $<0.001$ & $<0.001$ \\
\hline Crude protein, $\mathrm{g} \mathrm{kg}^{-1} \mathrm{DM}$ & 34.1 & 103.7 & 127.3 & 155.6 & 185.5 & $\hat{\mathrm{Y}}_{3}$ & 0.95 & $8.82<$ & $<0.001$ & 0.005 \\
\hline Neutral detergent insoluble protein, $\mathrm{g} \mathrm{kg}^{-1} \mathrm{DM}$ & 9.6 & 27.9 & 41.1 & 57.5 & 71.3 & $\hat{Y}_{4}$ & 0.99 & $16.02<$ & $<0.001$ & 0.898 \\
\hline Acid detergent insoluble protein, $\mathrm{g} \mathrm{kg}^{-1} \mathrm{DM}$ & 4.9 & 17.8 & 24.2 & 32.0 & 41.4 & $\hat{Y}_{5}$ & 0.99 & $17.53<$ & $<0.001$ & 0.653 \\
\hline Ether extract, $\mathrm{g} \mathrm{kg}^{-1} \mathrm{DM}$ & 28.3 & 14.1 & 12.1 & 22.8 & 27.1 & $\hat{\mathrm{Y}}_{6}$ & 0.82 & 17.95 & 0.249 & $<0.001$ \\
\hline Neutral detergent fiber corrected for ash and protein, $\mathrm{g} \mathrm{kg}^{-1} \mathrm{DM}$ & 809.5 & 693.3 & 622.7 & 593.2 & 563.6 & $\hat{\mathrm{Y}}_{7}$ & 0.91 & $1.6<$ & $<0.001$ & $<0.001$ \\
\hline Acid detergent fiber, $\mathrm{g} \mathrm{kg}^{-1} \mathrm{DM}$ & 628.2 & 609.9 & 527.1 & 526.3 & 535.9 & $\hat{\mathrm{Y}}_{8}$ & 0.73 & $3.98<$ & $<0.001$ & $<0.001$ \\
\hline Hemicellulose, $\mathrm{g} \mathrm{kg}^{-1} \mathrm{DM}$ & 236.6 & 177.4 & 175.3 & 178.3 & 171.6 & $\hat{Y}_{9}$ & 0.56 & 15.86 & 0.006 & 0.039 \\
\hline Cellulose, $\mathrm{g} \mathrm{kg}^{-1} \mathrm{DM}$ & 463.7 & 396.8 & 328.0 & 292.5 & 318.9 & $\hat{\mathrm{Y}}_{10}$ & 0.80 & $10.03<$ & $<0.001$ & 0.001 \\
\hline Lignin, $\mathrm{g} \mathrm{kg}^{-1} \mathrm{DM}$ & 124.9 & 159.5 & 176.7 & 197.9 & 221.7 & $\hat{\mathrm{Y}}_{11}$ & 0.99 & $10.38<$ & $<0.001$ & 0.856 \\
\hline Indigestible neutral detergent fiber, $\mathrm{g} \mathrm{kg}^{-1} \mathrm{DM}$ & 363.6 & 302.1 & 295.3 & 293.1 & 291.7 & $\hat{\mathbf{Y}}_{12}$ & 0.62 & $4.55<$ & $<0.001$ & $<0.001$ \\
\hline Indigestible $\mathrm{DM}, \mathrm{g} \mathrm{kg}^{-1} \mathrm{DM}$ & 412.1 & 349.7 & 350.0 & 349.9 & 340.2 & $\hat{\mathrm{Y}}_{13}$ & 0.60 & $4.57<$ & $<0.001$ & 0.001 \\
\hline
\end{tabular}

FM: Fresh matter; L: linear effect; Q: quadratic effect; $\mathrm{r}^{2}$ : coefficient of determination; $\mathrm{CV}$ : coefficient of variation.

Equations: $\hat{\mathrm{Y}}_{1}=196.936+6.696 \mathrm{DCBM} ; \hat{\mathrm{Y}}_{2}=30.380+2.646 \mathrm{DCBM} ; \hat{\mathrm{Y}}_{3}=50.284+7.095 \mathrm{DCBM} ; \hat{\mathrm{Y}}_{4}=10.912+3.057 \mathrm{DCBM} ; \hat{\mathrm{Y}}_{5}=6.628+$ $1.743 \mathrm{DCBM} ; \hat{\mathrm{Y}}_{6}=26.722-2.715 \mathrm{DCBM}+1.420 \mathrm{DCBM}^{2} ; \hat{\mathrm{Y}}_{7}=774.812-11.835 \mathrm{DCBM} ; \hat{\mathrm{Y}}_{8}=613.092-5.136 \mathrm{DCBM} ; \hat{\mathrm{Y}}_{9}=213.668-2.583 \mathrm{DCBM} ;$ $\hat{\mathrm{Y}}_{10}=438.768-7.878 \mathrm{DCBM} ; \hat{\mathrm{Y}}_{11}=129.732+4.640 \mathrm{DCBM} ; \hat{\mathrm{Y}}_{12}=339.700-3.053 \mathrm{DCBM} ; \hat{\mathrm{Y}}_{13}=389.092-2.870 \mathrm{DCBM}$.

Table 3. Carbohydrates and protein fractions of sugarcane silages containing different levels of detoxified castor-bean meal (DCBM).

\begin{tabular}{|c|c|c|c|c|c|c|c|c|c|c|}
\hline \multirow[b]{2}{*}{ Item } & \multicolumn{5}{|c|}{ Levels of DCBM $\left(\mathrm{g} \mathrm{kg}^{-1} \mathrm{FM}\right)$} & \multirow[b]{2}{*}{ Equations } & \multirow[b]{2}{*}{$\mathrm{r}^{2}$} & \multirow[b]{2}{*}{$\mathrm{CV}(\%)$} & \multicolumn{2}{|c|}{$P$ value } \\
\hline & 0 & 50 & 100 & 150 & 200 & & & & $\mathrm{~L}$ & $\mathrm{Q}$ \\
\hline \multicolumn{11}{|c|}{ Carbohydrate } \\
\hline Total carbohydrates, $\mathrm{g} \mathrm{kg}^{-1} \mathrm{DM}$ & 911.0 & 834.0 & 801.0 & 751.0 & 706.0 & $\mathrm{Y}_{1}$ & 0.98 & 1.7 & $<0.001$ & $<0.001$ \\
\hline Fraction $\mathrm{A}+\mathrm{B} 1, \mathrm{~g} \mathrm{~kg}^{-1} \mathrm{TC}$ & 112.0 & 169.0 & 222.0 & 209.0 & 202.0 & $\mathrm{Y}_{2}$ & 0.97 & 9.3 & $<0.001$ & 0.039 \\
\hline Fraction $\mathrm{B} 2, \mathrm{~g} \mathrm{~kg}^{-1} \mathrm{TC}$ & 489.0 & 468.0 & 408.0 & 399.0 & 385.0 & $\mathrm{Y}_{3}$ & 0.92 & 4.8 & $<0.001$ & 0.001 \\
\hline Fraction $\mathrm{C}, \mathrm{g} \mathrm{kg}^{-1} \mathrm{TC}$ & 398.0 & 362.0 & 368.0 & 390.0 & 409.0 & $\mathrm{Y}_{4}$ & 0.87 & 4.7 & $<0.001$ & $<0.001$ \\
\hline \multicolumn{11}{|c|}{ Nitrogen } \\
\hline Total $\mathrm{N}, \mathrm{g} \mathrm{kg}^{-1} \mathrm{DM}$ & 5.0 & 16.0 & 20.0 & 24.0 & 29.0 & $\mathrm{Y}_{5}$ & 0.95 & 8.8 & $<0.001$ & 0.009 \\
\hline Fraction $\mathrm{A}, \mathrm{g} \mathrm{kg}^{-1} \mathrm{TN}$ & 72.0 & 61.0 & 76.0 & 69.0 & 77.0 & $Y=71.2$ & - & 13.2 & 0.084 & $<0.001$ \\
\hline Fraction $\mathrm{B} 1+\mathrm{B} 2, \mathrm{~g} \mathrm{~kg}^{-1} \mathrm{TN}$ & 644.0 & 667.0 & 602.0 & 562.0 & 538.0 & $\mathrm{Y}_{6}$ & 0.86 & 6.6 & $<0.001$ & 0.005 \\
\hline Fraction $\mathrm{B} 3, \mathrm{~g} \mathrm{~kg}^{-1} \mathrm{TN}$ & 139.0 & 98.0 & 131.0 & 164.0 & 160.0 & $\mathrm{Y}_{7}$ & 0.42 & 22.3 & 0.023 & 0.023 \\
\hline Fraction $\mathrm{C}, \mathrm{g} \mathrm{kg}^{-1} \mathrm{TN}$ & 144.0 & 172.0 & 189.0 & 203.0 & 224.0 & $\mathrm{Y}_{8}$ & 0.99 & 14.6 & $<0.001$ & $<0.001$ \\
\hline
\end{tabular}

FM: Fresh matter; $\mathrm{r}^{2}$ : coefficient of determination; CV: coefficient of variation; L: linear effect; Q: quadratic effect; TC: total carbohydrates; TN: total N.

Equations: $\mathrm{Y}_{1}=899.72-9.868 \mathrm{DCBM} ; \mathrm{Y}_{2}=110.900+15.634 \mathrm{DCBM}-0.5604 \mathrm{DCBM} ; \mathrm{Y}_{3}=485.696-5.54640 \mathrm{DCBM} ; \mathrm{Y}_{4}=$ $394.185-6.27206 \mathrm{DCBM}+0.363143 \mathrm{DCBM}_{2} ; \mathrm{Y}_{5}=8.03600+1.1360 \mathrm{DCBM} ; \mathrm{Y}_{6}=666.772-6.34760 \mathrm{DCBM} ; \mathrm{Y}_{7}=117.268+$ $2.1556 \mathrm{DCBM} ; \mathrm{Y}_{8}=148.368+3.831 \mathrm{DCBM}$.

\section{Fermentation characteristics and losses in silage}

A positive response, linear for $\mathrm{pH}$ and quadratic for $\mathrm{N}^{-\mathrm{NH}_{3}}$, as a function of increased DCBM levels (Table 4). The inclusion of increased doses of DCBM reduced linearly $(\mathrm{P}<0.01)$ and quadratically $(\mathrm{P}<0.01)$ total DM losses, ranging from $35.4 \%$ losses in silage without addition of DCBM to $8.0 \%$ losses in silage with $200 \mathrm{~g} \mathrm{~kg}^{-1}$ DCBM. As the level of DCBM increased (from 0 to $200 \mathrm{~g} \mathrm{~kg}^{-1}$ ), there was a decrease of $64 \%$ in gas losses and $87 \%$ in losses through effluents (Table 5). For the values of DM recovery index (DMREC), a positive linear response was observed. The addition of 200 $\mathrm{g} \mathrm{kg}^{-1}$ castor bean meal increased DMREC by $142 \%$ when compared to silage without additive.

\section{Aerobic stability}

The aerobic stability of the silage presented quadratic behavior $(\mathrm{P}<0.01)$. The sugarcane silage without additive was the most stable $\left(144 \mathrm{~h}\right.$ ), but the silage that received $200 \mathrm{~g} \mathrm{~kg}^{-1}$ DCBM was the most stable among the ones with DCBM addition (Table 5). 
Table 4. Temperature variables associated with aerobic stability of sugarcane silages supplemented with different levels of detoxified castor-bean meal (DCBM).

\begin{tabular}{|c|c|c|c|c|c|c|c|c|c|c|}
\hline \multirow[b]{2}{*}{ Variable } & \multicolumn{5}{|c|}{ Levels of DCBM $\left(\mathrm{g} \mathrm{kg}^{-1} \mathrm{FM}\right)$} & \multirow[b]{2}{*}{ Equations } & \multirow[b]{2}{*}{$r^{2}$} & \multirow[b]{2}{*}{$\mathrm{CV}(\%)$} & \multicolumn{2}{|c|}{ P value } \\
\hline & 0 & 50 & 100 & 150 & 200 & & & & $\mathrm{~L}$ & Q \\
\hline Stabi & 44.2 & 50 & 3 & 38 & 51.6 & $\hat{Y}_{1}$ & 0.94 & 06 & $<0.01$ & $<c$ \\
\hline CAT & -4.4 & 22 & & 41 & & $\hat{\mathrm{Y}}$ & 0.99 & & $<0.01$ & $<0.01$ \\
\hline CAT $10 \mathrm{~d}$ & 32.2 & 68.9 & 95.4 & 98.7 & 97.6 & $\hat{\mathrm{Y}}_{4}$ & 0.99 & 13.48 & $<0.01$ & $<0.01$ \\
\hline $\mathrm{pH} 0$ & 3.02 & 2.98 & 3.16 & 3.26 & 3.4 & $\hat{Y}$ & 0.90 & 1.41 & 1.41 & $<0.001$ \\
\hline $\mathrm{pH} 10$ & 3.4 & 5.6 & 8.7 & 8.7 & 8.7 & $\hat{\mathrm{Y}}_{5}$ & 0.97 & 12.05 & 12.05 & $<0.001$ \\
\hline
\end{tabular}

FM: Natural matter; $\mathrm{r}^{2}$ : coefficient of determination; CV: coefficient of variation; L: linear effect Q: quadratic effect; CAT: cumulative average temperature by the difference between room temperature and the temperature of the silages in the first $5 \mathrm{~d}$, from the fifth to the tenth day and from zero to $10 \mathrm{~d}$ of aerobic exposure.

Equations: $\hat{\mathrm{Y}}_{1}=136.64-17.376 \mathrm{DCBM}+0.672 \mathrm{DCBM}^{2} ; \hat{\mathrm{Y}}_{2}=-4.159+5.3486 \mathrm{DCBM}$ $-0.1552 \mathrm{DCBM}^{2} ; \hat{\mathrm{Y}}_{3}=35.685+3.722 \mathrm{DCBM}-0.1266 \mathrm{DCBM}^{2} ; \hat{\mathrm{Y}}_{4}=31.526+9.0706 \mathrm{DCBM}$ $-0.2818 \mathrm{DCBM}^{2} ; \hat{\mathrm{Y}}_{5}=3.2257+0.7065 \mathrm{DCBM}-0.02148 \mathrm{DCBM}^{2}$.

Table 5. Losses and recovery of DM from sugarcane silages supplemented with increasing levels of detoxified castor-bean meal (DCBM).

\begin{tabular}{|c|c|c|c|c|c|c|c|c|c|c|}
\hline \multirow[b]{2}{*}{ Variable } & \multicolumn{5}{|c|}{ Levels of DCBM ( $\left.\mathrm{g} \mathrm{kg}^{-1} \mathrm{FM}\right)$} & \multirow[b]{2}{*}{ Equations } & \multirow[b]{2}{*}{$r^{2}$} & \multirow[b]{2}{*}{$\mathrm{CV}(\%)$} & \multicolumn{2}{|c|}{$P$ value } \\
\hline & 0 & 50 & 100 & 150 & 200 & & & & $\mathrm{~L}$ & Q \\
\hline Loss of total DM, $\mathrm{g} \mathrm{kg}^{-1} \mathrm{DM}$ & 354.0 & 226.0 & 145.0 & 93.0 & 80.0 & $\hat{\mathrm{Y}}^{1}$ & 0.92 & 14.7 & $<0.01$ & $<0.01$ \\
\hline Gas losses, $\mathrm{g} \mathrm{kg}^{-1} \mathrm{DM}$ & 246.0 & 179.9 & 130.3 & 108.4 & 89.2 & $\hat{\mathrm{Y}}^{2}$ & 0.93 & 2.47 & $<0.01$ & $<0.01$ \\
\hline Effluent losses, $\mathrm{kg} \mathrm{t}^{-1}$ & 210.0 & 130.0 & 32.0 & 28.0 & 28.0 & $\hat{\mathrm{Y}}^{3}$ & 0.95 & 3.5 & $<0.01$ & $<0.01$ \\
\hline Dry matter recovery index, $\mathrm{g} \mathrm{kg}^{-1} \mathrm{DM}$ & 645.0 & 773.0 & 854.0 & 906.0 & 919.0 & $\hat{\mathrm{Y}}^{4}$ & 0.98 & 1.0 & $<0.01$ & $<0.01$ \\
\hline
\end{tabular}

FM: Fresh matter; $\mathrm{r}^{2}$ : coefficient of determination; CV: coefficient of variation; L: linear effect; Q: quadratic effect.

Equations: $\hat{\mathrm{Y}}_{1}=316.579-13.6226 \mathrm{DCBM} ; \hat{\mathrm{Y}}_{2}=227.75-7.7 \mathrm{DCBM} ; \hat{\mathrm{Y}}_{3}=215.39-23.837 \mathrm{DCBM}+0.726 \mathrm{DCBM}{ }^{2} ; \hat{\mathrm{Y}}_{4}=683.421+13.6226 \mathrm{DCBM}$.

\section{DISCUSSION}

The addition of DCBM increased DM and CP contents of the silages since the by-product presented a higher DM $(925.2$ vs. $275.9 \mathrm{~g} \mathrm{~kg}^{-1}$ ) and CP content (448.4 vs. $26.6 \mathrm{~g} \mathrm{~kg}^{-1}$ ) than sugarcane. There was an increase of $539 \%$ in CP from $3.44 \%$ without additive to $18.55 \% \mathrm{CP}$ in the treatment with $200 \mathrm{~g} \mathrm{~kg}^{-1}$ DCBM. These results are in agreement with Oliveira et al. (2015), who also evaluated the inclusion of castor-bean meal to sugarcane silage and observed an increase of $714 \%$ in $\mathrm{CP}$ content of the silages.

The reduction in the contents of NDFap and ADF was 303.8 and $147.0 \mathrm{~g} \mathrm{~kg}^{-1}$ respectively, due to the addition of DCBM. The DCBM is a protein concentrate that presents lower hemicellulose $\left(46.2 v s .71 .9 \mathrm{~g} \mathrm{~kg}^{-1}\right)$ and cellulose $(121.8 v s .363 .1$ $\mathrm{g} \mathrm{kg}^{-1}$ ) compared to sugarcane. However, the decrease - 50\% lower - in ADF content may be due to the high lignin content $\left(300.9 \mathrm{~g} \mathrm{~kg}^{-1}\right)$ of DCBM. In fact, the addition of DCBM increased lignin content by $177 \%$. Possibly, the presence of highly lignified husk (Andrade et al., 2013) in castor-bean meal was determinant for the increase of silage lignin.

The decrease in total carbohydrate contents can be attributed to the replacement of sugarcane with TC $\left(950.5 \mathrm{~g} \mathrm{~kg}^{-1}\right)$ in DM by castor-bean meal with only $418.0 \mathrm{~g} \mathrm{~kg}^{-1} \mathrm{CT}$. These findings are in agreement with Ribeiro et al. (2014), who added castor-bean cake to elephant grass silage and also observed a decrease in the total carbohydrate contents of the silage.

Before ensiling, the fraction A + B1 corresponded to $466.9 \mathrm{~g} \mathrm{~kg}^{-1}$ of the total carbohydrates, while in the silage with 0 $\mathrm{g} \mathrm{kg}^{-1}$ DCBM the same fraction did not exceed $112.0 \mathrm{~g} \mathrm{~kg}^{-1}$. However, the addition of DCBM was efficient in conserving residual carbohydrates in sugarcane silage, since the addition of the by-product resulted in contents of $200 \mathrm{~g} \mathrm{~kg}^{-1}$, on average, in the fraction $\mathrm{A}+\mathrm{B} 1$. The presence of higher residual carbohydrate content of fraction $\mathrm{A}+\mathrm{B} 1$ in silages with the inclusion of DCBM can be attributed to the improvement of the fermentation pattern of these silages. The increase in DM reduced water activity, thus reducing the proliferation of undesirable microorganisms that use soluble carbohydrates as substrate (Muck, 2010). 
The DCBM presented low levels of hemicellulose $\left(46.2 \mathrm{~g} \mathrm{~kg}^{-1}\right)$ and cellulose $\left(121.8 \mathrm{~g} \mathrm{~kg}^{-1}\right)$, which explains the lower percentages of fraction B2 of carbohydrates of the enriched silages. Similarly, Andrade et al. (2010) observed that the addition of cocoa meal caused a decrease in the fraction B2 of the silage enriched with this residue. However, the high lignin content (300.9 $\mathrm{g} \mathrm{kg}^{-1} \mathrm{DM}$ ) of the DCBM present in the DCBM justifies the high content of the fraction C observed in the silages.

Castor-bean is a protein concentrate (Cobianchi et al., 2012) and its addition to sugarcane increased TN of the ensiled mixture. The DCBM presented high neutral detergent insoluble $\mathrm{N}$ (NDIN) content $\left(354.8 \mathrm{~g} \mathrm{~kg}^{-1} \mathrm{CP}\right.$ ), and its addition in silage was responsible for raising the level of slow degradation $\mathrm{N}$ (B3) and reducing the rapid degradation fraction (B1 + B2). The increase of the fractions B3 and C of the protein with addition of DCBM is due to the high levels of NDIN and acid detergent insoluble $\mathrm{N}$ (ADIN) in the meal. The alkalinization promoted by calcium hydroxide causes protein denaturation and reduces protein solubility of the by-product (Oliveira et al., 2010). Consequently, the addition of DCBM increases values of slow degradation and indigestible protein fractions (B3 and $\mathrm{C}$ ) in the enriched silages.

The in vitro DM digestibility (IVDMD) was quadratically affected with a maximum value of $662 \mathrm{~g} \mathrm{~kg}^{-1}$ at the level of $151.4 \mathrm{~g} \mathrm{~kg}^{-1}$ castor-bean meal. Santos et al. (2018) also observed that the addition of up to $150 \mathrm{~g} \mathrm{~kg}^{-1}$ of common bean residue improved the IVDMD of sugarcane silage.

The $\mathrm{pH}$ of the silages was between $2.99\left(0 \mathrm{~g} \mathrm{~kg}^{-1} \mathrm{DCBM}\right)$ and $3.37\left(200 \mathrm{~g} \mathrm{~kg}^{-1} \mathrm{DCBM}\right)$ which are close to the values reported by Santos et al. (2015) for sugarcane silage, and within the optimum range established by McDonald et al. (1991). The increase in $\mathrm{pH}$ as a function of the amount of DCBM added is related to the alkalinizing power of calcium hydroxide (Carvalho et al., 2012) added to castor-bean meal for detoxification. Regarding $\mathrm{N}^{-\mathrm{NH}_{3}}$ values (\% TN), data demonstrate that from $50 \mathrm{~g} \mathrm{~kg}^{-1} \mathrm{DCBM}$, there is a reduction of ammoniacal $\mathrm{N}$ from 6.0 to $4.0 \mathrm{mg} \mathrm{dL}^{-1}$. At the level of 200 $\mathrm{g} \mathrm{kg}^{-1}$ additive, $\mathrm{N}^{-\mathrm{NH}_{3}}$ did not exceed $2.5 \mathrm{mg} \mathrm{dL}^{-1}$.

The addition of DCBM increased DM contents of the ensiled mass, resulting in an increase in the osmotic capacity of the silage and greater fluid retention and reduction of generated effluents. In addition, the elevation of silage DM also increases the homofermentative bacteria population, which is related to lower gas losses (Muck, 2010).

The aerobic stability of silage was impaired by the addition of DCBM. Probably, the increase in residual carbohydrates, which also occurred with the addition of DCBM, made the silage more susceptible to deterioration (Conaghan et al., 2011). However, the level of $200 \mathrm{~g} \mathrm{~kg}^{-1}$ DCBM presented the greatest stability among the enriched silages. This fact can be explained by the greater presence of calcium hydroxide that increases aerobic stability of sugarcane silages (Custódio et al., 2016).

\section{CONCLUSION}

The addition of $150 \mathrm{~g} \mathrm{~kg}^{-1}$ detoxified castor bean meal improved the content of residual carbohydrates and crude protein in silage and reduced losses during sugarcane ensilage.

\section{ACKNOWLEDGEMENTS}

The authors thank Coordination for the Improvement of Higher Education Personnel (CAPES) for the granting of a postgraduate scholarship (Master degree) and the National Council for Scientific and Technological Development (CNPq) for funding this research.

\section{REFERENCES}

Andrade, P.X., Andrade, M.F., Urbano, S.A., Azevedo, M., Félix, S.C., Siqueira, M.C., et al. 2013. Castor beans hulls as a replacement for Tifton 85 hay in lamb diets. Tropical Animal Health and Production 45:1191-1196.

Andrade, I.V.O., Pires, A.J.V., Carvalho, G.G.P., Veloso, C.M., e Bonomo, P. 2010. Fracionamento de proteína e carboidratos em silagens de capim-elefante contendo subprodutos agrícolas. Revista Brasileira de Zootecnia 39:2342-2348.

Andrade, F.L., Rodrigues, J.P.P., Detmann, E., Valadares Filho, S.C.V., Castro, M.M.D., Trece, A.S., et al. 2016. Nutritional and productive performance of dairy cows fed corn silage or sugarcane silage with or without additives. Tropical Animal Health and Production 48:747-753. 
AOAC. 2005. Official methods of analysis. 18 ed. Association Analytical Chemists (AOAC) Gaithersburg, Maryland, USA.

Bernardes, T.F., Reis, R.A., Siqueira, G.R., Amaral, R.C., e Pires, A.J.V. 2007. Estabilidade aeróbia da ração total e de silagens de capim-marandu tratadas com aditivos químicos e bacterianos. Revista Brasileira de Zootecnia 36:754-762.

Carvalho, B.F., Avila, C.L.S., Pinto, J.C., Pereira, M.N., and Schwan, R.F. 2012. Effects of propionic acid and Lactobacillus buchneri (UFLA SIL 72) addition on fermentative and microbiological characteristics of sugar cane silage treated with and without calcium oxide. Grass and Forage Science 67:462-471.

Casali, A.O., Detmann, E., Valadares Filho, S.C., Pereira, J.C., Henriques, L.T., Freitas, S.G., et al. 2008. Influence of incubation time and particles size on indigestible compounds contents in cattle feeds and feces obtained by in situ procedures. Revista Brasileira de Zootecnia 37:335-342.

Cavali, J., Pereira, O.G., Valadares Filho, S.C., Santos, E.M., Carvalho, G.G.P., Santos, M.V., et al. 2010. Bromatological and microbiological characteristics of sugarcane silages treated with calcium oxide. Revista Brasileira de Zootecnia 39:1398-1408.

Cobianchi, J.V., Oliveira, A.S., Campos, J.M.S., Guimarães, A.V., Valadares Filho, S.C., Cobianchi, F.P., et al. 2012. Productive performance and efficiency of utilization of the diet components in dairy cows fed castor meal treated with calcium oxide. Revista Brasileira de Zootecnia 41:2238-2248.

Conaghan, P., O'Kiely, P., and O'Mara, F.P. 2011. Possibilities of increasing the residual water-soluble carbohydrate concentration and aerobic stability of low dry-matter perennial ryegrass silage through additive and cultivar use. Grass and Forage Science 67:177-198.

Custódio, L., Morais, G., Daniel, J.L.P., Pauly, T., and Nussio, L.G. 2016. Effects of chemical and microbial additives on clostridium development in sugarcane (Saccharum officinarum L.) ensiled with lime. Grassland Science 62:135-143.

Daniel, J.L.P., Santos, M.C., Zopollatto, M., Huhtanen, P., and Nussio, L.G. 2013a. A data-analysis of lime addition on the nutritive value of sugarcane in Brazil. Animal Feed Science and Technology 184:17-23.

Daniel, J.L.P., Weiss, K., Custódio, L., Sá-Neto, A., Santos, M.C., Zopollatto, M., et al. 2013b. Occurrence of volatile organic compounds in sugarcane silages. Animal Feed Science and Technology 185:101-105.

Freire, J.M., Silva, A.M.A., Carneiro, H., Filho, J.M.P., Rocha, L.B., and Bidler, D.C. 2017. In vitro degradation and gas production of brachiaria grass with levels of biodiesel byproducts. Acta Scientiarum. Animal Sciences 39:170-175.

Gionbelli, T.R.S., Veloso, C.M., Gionbelli, M.P., Novais, M.A.S., Silva, A.L., Espechit, C.J.B., et al. 2014. Utilization of castor bean meal treated with calcium hydroxide, fed wet or dry, by lambs. Livestock Science 168:76-83.

Hall, M.B. 2003. Challenges with nonfiber carbohydrate methods. Journal of Animal Science 81:3226-3232.

Holden, L.A. 1999. Comparison of methods of in vitro dry matter digestibility for ten feeds. Journal Dairy Science 82:1791-1794.

Jobim, C.C., Nussio, L.G., Reis, R.A., and Schmidt, P. 2007. Methodological advances in evaluation of preserved forage quality. Revista Brasileira de Zootecnia 36:101-119.

McDonald, P., Henderson, A.R., and Heron, S.J.E. 1991. The biochemistry of silage. $2^{\text {nd }}$ ed. 340 p. Chalcomb Publications, Marlow, UK.

Menezes, D.R., Costa, R.G., Araújo, G.G.L., Pereira, L.G.R. Nunes, A.C.B., Henrique, L.T., et al. 2015. Cinética ruminal de dietas contendo farelo de mamona destoxificado. Arquivo Brasileiro de Medicina Veterinária e Zootecnia 67:636-641.

Moreira, M.N., Silva, A.M.A., Bezerra, L.R., Carneiro, H., Morais, R.K.O., and Medeiros, F.F. 2016. Effect of replacement of sugarcane by oilseed press cakes in greenhouse gases and volatile fatty acids production in vitro. Acta Scientiarum. Animal Sciences 38:293-300.

Moreira, M.N., Silva, A.M.A., Carneiro, H., Bezerra, L.R., Morais, R.K.O., and Medeiros, F.F. 2014. In vitro degradability and total gas production of biodiesel chain byproducts used as a replacement for cane sugar feed. Acta Scientiarum. Animal Science 36:399-403.

Muck, R.E. 2010. Silage microbiology and its control through additives. Revista Brasileira de Zootecnia 39:183-191.

Novinski, C.O., Junges, D., Schmidt, P., Rossi Junior, P., Carvalho, J.P.G., and Teixeira, R.A. 2012. Methods of lab silo sealing and fermentation characteristics and aerobic stability of sugarcane silage treated with microbial additive. Revista Brasileira de Zootecnia 41:264-270.

O'Kiely, P., Moloney, A., Keating, T., and Shiels, P. 1999. Maximising output of beef within cost efficient, environmentally compatible forage conservation systems. 64 p. End of Project Reports, Teagasc-Agriculture and Food Development Authority. Grange Research Centre, Dunsany, Meath, Ireland.

Oliveira, A.S., Campos, J.M.S., Oliveira, M.R.C., Brito, A.F., Valadares Filho, S.C., Detmann, E., et al. 2010. Nutrient digestibility, nitrogen metabolism and hepatic function of sheep fed diets containing solvent or expeller castorseed meal treated with calcium hydroxide. Animal Feed Science Technology 158:15-28.

Oliveira, A.C., Garcia, R., Pires, A.J.V., Oliveira, H.C., Almeida, V.V.S., Silva, R.R., et al. 2015. Chemical composition and fermentation characteristics of sugar cane silage enriched with detoxified castor bean meal. Arquivo Brasileiro de Medicina Veterinária e Zootecnia 67:181-188.

Ribeiro, L.S.O., Pires, A.J.V., Carvalho, G.G.P., Pereira, M.L.A., Santos, A.B., and Rocha, L.C. 2014. Fermentation characteristics, chemical composition and fractionation of carbohydrates and crude protein of silage of elephant grass wilted or with addition of castor bean meal. Semina: Ciências Agrárias 35:1447-1462. 
Santos, K.C., Magalhães, A.L.R., Conceição, M.G., Carvalho, F.F.R., and Ferreira, G.D.G. 2018. Common bean residue as additive in sugarcane silage. Revista Ciência Agronômica 49:159-166.

Santos, W.C.C., Nascimento, W.G., Magalhães, A.L.R., Silva, D.K.A., Silva, J.C.S., Santana, A.V.S., et al. 2015. Nutritive value, total losses of dry matter and aerobic stability of the silage from three varieties of sugarcane treated with commercial microbial additives. Animal Feed Science and Technology 204:1-8.

Silva, D.J., e Queiroz, A.C. 2002. Análise de alimentos: métodos químicos e biológicos. $3^{\mathrm{a}}$ ed. 235 p. Universidade Federal de Viçosa (UFV), Viçosa, Minas Gerais, Brasil.

Siqueira, G.R., Roth, M.T.P., Moretti, M.H., Benatti, J.M.B., e Resende, F.D. 2012. Uso da cana-de-açúcar na alimentação de ruminantes. Revista Brasileira de Saúde e Produção Animal 13:991-1008.

Sniffen, C.J., O’Connor, D.J., Van Soest, P.J., Fox, D.G., and Russel, J.B. 1992. A net carbohydrate and protein system for evaluating cattle diets: carbohydrate and protein availability. Journal of Dairy Science 70:3562-3577.

Tilley, J.M.A., and Terry, R.A. 1963. A two-stage technique for the in vitro digestion forage crops. Grass and Forage Science 18:104-111.

Van Soest, P.J., Robertson, J.B., and Lewis, B.A. 1991. Methods for dietary fiber, neutral detergent fiber, and nonstarch polysaccharides in relation to animal nutrition. Journal of Dairy Science 74:3583-3597. 